\title{
ADSORPTION EQUILIBRIUM AND DYNAMICS OF LACTASE/CM-SEPHADEX SYSTEM
}

\author{
Şebnem HARSA ${ }^{1 *}$ Yekta GÖKSUNGUR ${ }^{2}$ Ulgar GÜVENÇ ${ }^{2}$
}

1 Izmir Institute of Technology, Anafartalar cad.

No:904, Basmane 35220, Izmir-Turkey

2 Dept. of Food Eng., Faculty of Engineering, Ege University 35100, Bornova, Izmir.Turkey

\section{SUMMARY}

Partitioning behaviour and adsorption isotherms of lactase/CM-Sephadex system at equilibrium were investigated together with the adsorption kinetics in this study. Maximum adsorption was obtained at the $\mathrm{pH}$ values between 5.5-6.0. Adsorption isotherm was a close fit to the Langmuir model.

\section{INTRODUCTION}

Lactase ( $\beta$-galactosidase) enzyme preparations are widely used to hydrolyse lactose in milk, milk products and whey (byproduct of dairy industry which cause environmental problems due to their high biological oxygen demand), giving a mixture of glucose and galactose for consumers who suffer from lactose intolerance. These monosaccharides are sweeter and more soluble than lactose; furthermore, glucose and galactose are more readily fermented than lactose.

Lactase can be produced by Kluyveromyces marxianus which is a potential new source of commercial enzymes. Our aim is to obtain data in order to design an appropriate separation and immobilization scheme for lactases from $\mathrm{K}$. marxianus using lowcost ion-exchangers.

Within this context, we studied the equilibrium and dynamic behaviour of lactase/Sephadex system. Firstly, ionisation of adsorbate and adsorbent was determined from the titration curves. The effect of $\mathrm{pH}$ and gel concentration on the equilibrium partition coefficients was investigated. Finally, adsorption isotherms and kinetics were generated under the optimal conditions and suitable mathematical models were discussed. These will unveil information relevant to both adsorption based separation schemes and immobilized enzyme reaction systems. In both cases, knowledge of the equilibrium and dynamic behaviour of relevant species is key to process design and optimisation.

MATERIALS and METHOD

Carboxymethyl (CM) - Sephadex C-50 and lactase (Lactozym) were the products of Pharmacia and Novo Nordisk, respectively. This enzyme was the purified preparation of Novo and contained no other proteins ( 3000 Units/mL).

The binding capacity of CM-Sephadex and enzyme as a function of $\mathrm{pH}$ was obtained by $\mathrm{pH}$ titration with $0.1 \mathrm{M} \mathrm{HCL} ; 0.5 \mathrm{~mL}$ lactase enzyme (1500 Units) was used in $10 \mathrm{~mL}$ suitable buffer solutions to conduct the adsorption experiments. Enzyme solutions in 
different $\mathrm{pH}$ (pH 2.5-10) buffers (citrate, acetate and phosphate buffers, $0.1 \mathrm{M})$ were contacted with $0.5 \mathrm{~g}$ of hydrated and equilibrated gel. To determine the effect of gel:liquid ratio, different bulk volume of hydrated gel $\left(\mathrm{V}_{\mathrm{g}} / \mathrm{V}=0.02-0.5\right)$ were used. Samples were placed to the incubator with shaking at $28^{\circ} \mathrm{C}$ for 24 hours and analysed for protein (using the Lowry method) when the solution approaches to equilibrium. Partition coefficients indicate the fraction of adsorbed protein at equilibrium, and estimated from the equation of ( $f=q / p)$, where $q$ and $p$ are the equilibrium concentrations of adsorbed protein and free protein.

Adsorption isotherm experiments were conducted for different enzyme concentrations at pH 6.0 at $28^{\circ} \mathrm{C}$. Gels with different enzyme concentrations were placed into an incubator and stirred continuously. Equilibrium solution concentrations were determined approximately 24 hours later and the amount of enzyme adsorbed by $1 \mathrm{~mL}$ of hydrated was calculated from the difference of the initial and equilibrium solution concentrations.

A graph was plotted against the solution concentration at equilibrium (p) and adsorbed enzyme concentration inside the pellets (q). The calculations for isotherm equations were done and model line was also drawn on the graph.

To conduct the dynamic experiments, samples were taken at intervals and protein concentration at each free solution was

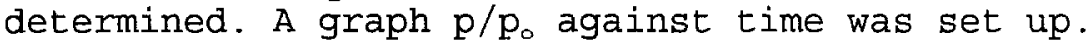

\section{RESULTS and DISCUSSION}

Ionisation of adsorbate and adsorbent. From the titration curves of lactase and CM-Sephadex, the ionisation of adsorbate and adsorbent was calculated and values are shown in Figure 1.

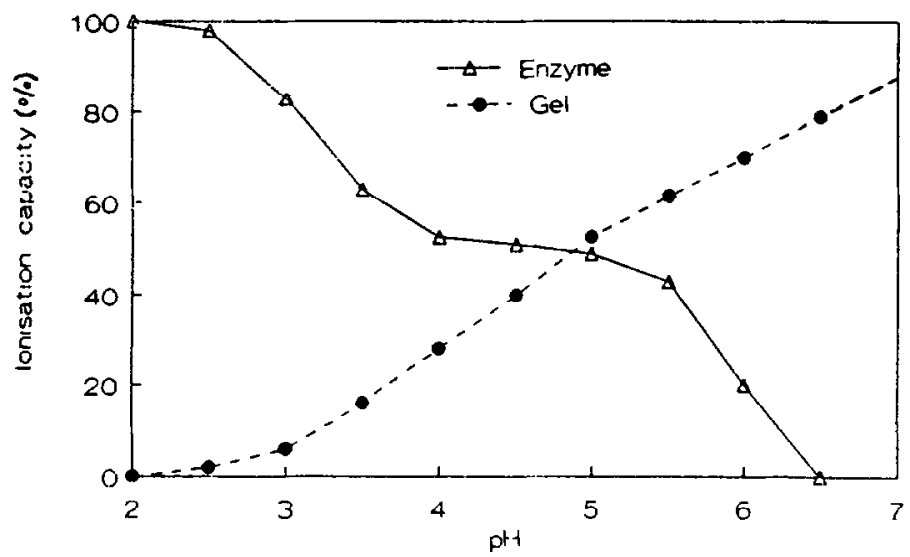

Figure 1: Ionisation of adsorbate and adsorbent

The gel is fully (negatively) charged at pH above 7.0; below that level, its net charge decreases sharply, and at $\mathrm{pH} 5.0$ only half of its potential binding capacity is active. On the other hand, at the isoelectric point (here 6.5), the net charge of the enzyme is zero. At lower $\mathrm{pH}$, the molecule becomes (positively) charged: at pH 5.0 about $50 \%$ of its total ionisation capacity is present, whereas at $\mathrm{pH} 3.0$ this increases to $83 \%$. The lactase is fully charged at very low $\mathrm{pH}(\mathrm{pH} 2.0)$. At above the isoelectric point, the net charge of the enzyme is negative (ie. the same as the adsorbent) and no electrostatic binding will occur. 
Effect of $\mathrm{pH}$ on partitioning. In Figure 2, the minimum value of partition coefficients were found at the pH values above 7.0 and below 4.0. Partitioning behaviour shows a rapid increase up to $\mathrm{pH} 6.0$ and at $\mathrm{pH}$ values between $5.5-6.0$ the optimum was observed. At this $\mathrm{pH}$ value the partition coefficient reaches its value of about 15.0. Below this pH partition coefficient started decreasing and at $\mathrm{pH} 9.0$ and above nearly no adsorption was recorded.

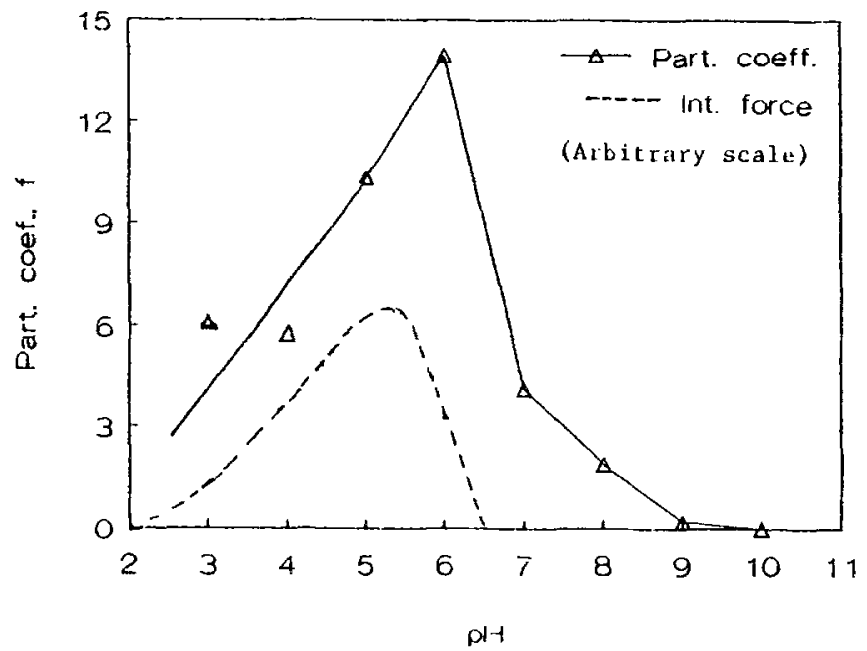

Figure 2: Effect of $\mathrm{pH}$ on the partition coefficient

According to Coulomb's law the interaction force between unlike charges $e_{1}, e_{2}$ is proportional to $e_{1}{ }^{*} e_{2}$. Thus, the net interaction force between the protein and matrix should be proportional to the product of the fractional degree of ionisation of each component (Harsa et al., 1990). The region of maximum partition coefficient corresponds to the region of maximum ionic interaction, as seen from Figure 2 .

Effect of gel concentration. A mass balance on protein shows that:

$$
\mathrm{V} \mathrm{p}_{\mathrm{o}}=\mathrm{Vp}+\mathrm{V}_{\mathrm{g}} \mathrm{q}
$$

Where $V$ and $V_{g}$ are the bulk liquid and gel volume respectively, $p_{0}$ is the initial concentration of protein in the liquid phase, and $\mathrm{p}$ and $\mathrm{q}$ are the final concentrations of unbound and bound protein respectively. It can be shown that:

$$
\mathrm{f}=\frac{\left(\mathrm{p}_{\circ} / \mathrm{p}\right)-1}{v_{g} / v}
$$

Equation (2) shows the relation between $V_{g} / V$ and the partition coefficient. The partition coefficient can be expressed in terms of the Langmije parameters as follows:

$$
\mathrm{f}=\mathrm{q} / \mathrm{p}=\mathrm{q}_{\mathrm{m}} /\left(\mathrm{K}_{\mathrm{p}}+\mathrm{p}\right)
$$

From equation the upper limit value for $\mathrm{K}$ is obtained when $\mathrm{p} \longrightarrow 0$, and is given by:

$$
\mathrm{f}=\mathrm{q}_{\mathrm{m}} / \mathrm{K}_{\mathrm{p}}
$$

To conduct the experiments $V_{g} / V$ was changed, the same 
concentration of enzyme was used all the time. As $V_{g} / V$ increased the partition coefficient decreased. The maximum value of partition coefficient was obtained for $V_{g} / V=0.03-0.05$. At the value of 0.1 partition coefficient start to fall down and reaches its minimum at 0.3 . In all adsorption experiments the $V_{g} / V$ value of 0.05 was used.

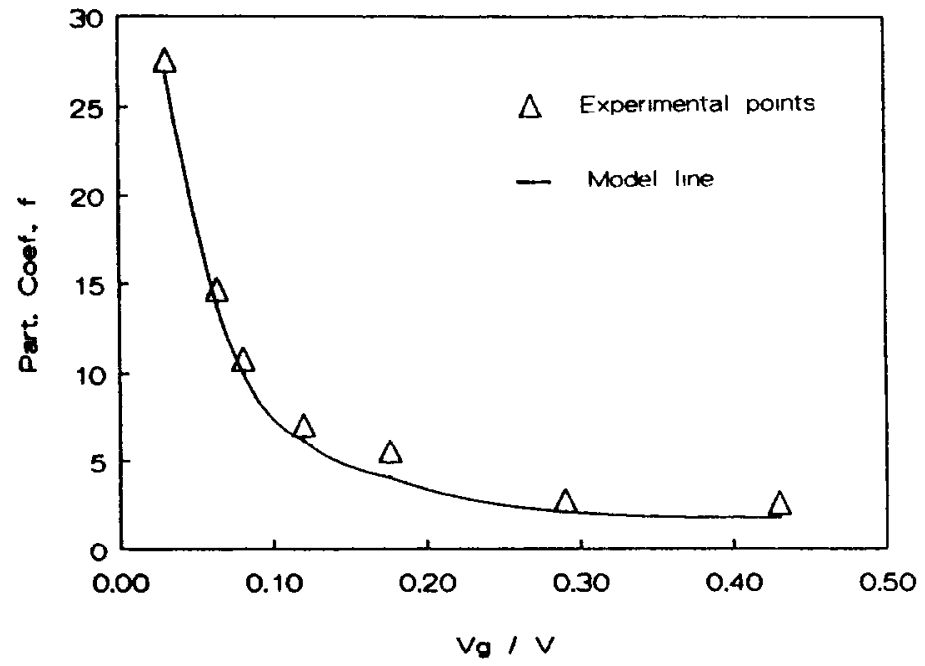

Figure 4: Effect of gel concentration on equilibrium

Adsorption isotherms. Adsorption isotherm experiments were conducted at $\mathrm{pH} 6.0$, temperature $28^{\circ} \mathrm{C}$, since these values were found to be the optimal for the enzyme stability and maximum adsorption. Figure 4 shows the adsorption isotherm.

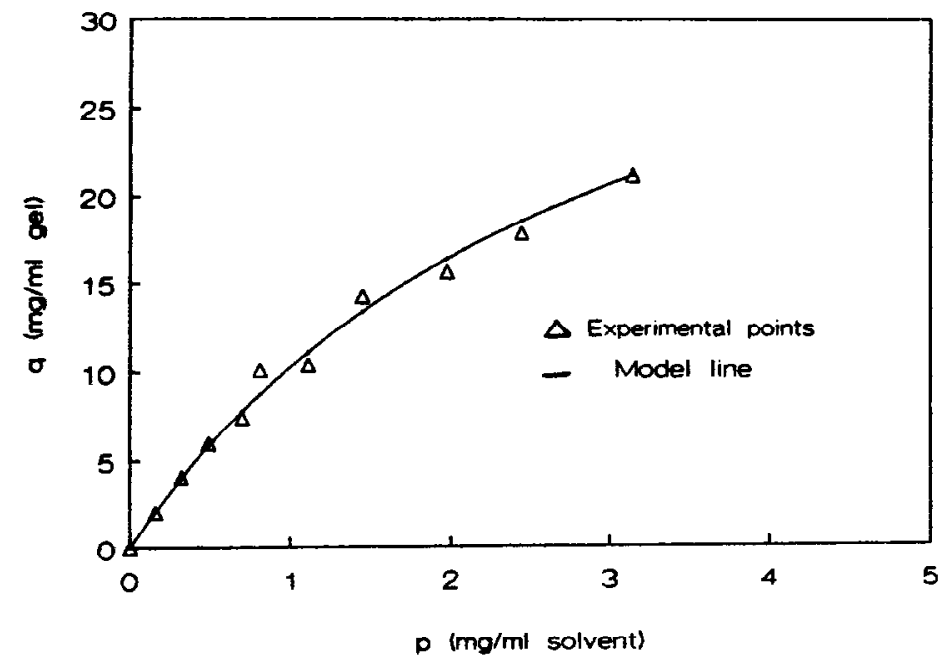

Figure 4: Adsorption isotherm of lactase on CM-Sephadex resin

Adsorption isotherms show the distribution of protein concentration between the liquid phase at equilibrium (p) and gel phase (q). There are several equations to describe the adsorption isotherms for ion exchange chromatography. These are linear, Freundlich and Langmuir isotherms. The most applicable and robust one is Langmuir model, which is shown below:

$$
q=q_{m} p /\left(k_{p}+p\right)
$$


Using this model it is possible to calculate the parameters which are quite important for the design and scale-up of chromatographic separation purposes. $\mathrm{K}_{\mathrm{p}}$ is a dissociation constant for adsorbent-adsorbate complex, $q_{m}$ is the maximum adsorption capacity of the gel. The value of $\mathrm{q}_{m}$ for the lactase/CM-Sephadex system is approximately $42 \mathrm{mg}$ protein/ml gel. Dissociation constant $\mathrm{K}_{\mathrm{p}}$ was calculated as $3.1 \mathrm{mg} / \mathrm{ml}$ solvent.

Adsorption kinetics. Determination of adsorption kinetics of an enzyme/ion-exchange system is important to understand how fast the equilibrium has been reached. To know the mechanism involved during adsorption has great importance in the design and scale-up of an adsorption system.

At equilibrium the rate of adsorption can be written:

$$
-V d(p) / d(t)=k A\left(p-p^{*}\right)
$$

where $V$ is the bulk solvent volume and $A$ is the bead interfacial surface area.

Equations (5), and (6) provide a simplified model for the kinetics of adsorption. Details of calculations were given elsewhere (Harsa et al., 1993).

$$
Z=1-e^{-k a \alpha^{\prime} t} / \alpha^{\prime}
$$

Equation (7) represents a simplified model for batch adsorption kinetics in a stirred vessel, in terms of a global mass transfer coefficient, ka, the Langmuir parameters $q_{m} \& k_{p}$, and the gel and solvent volume ratio.

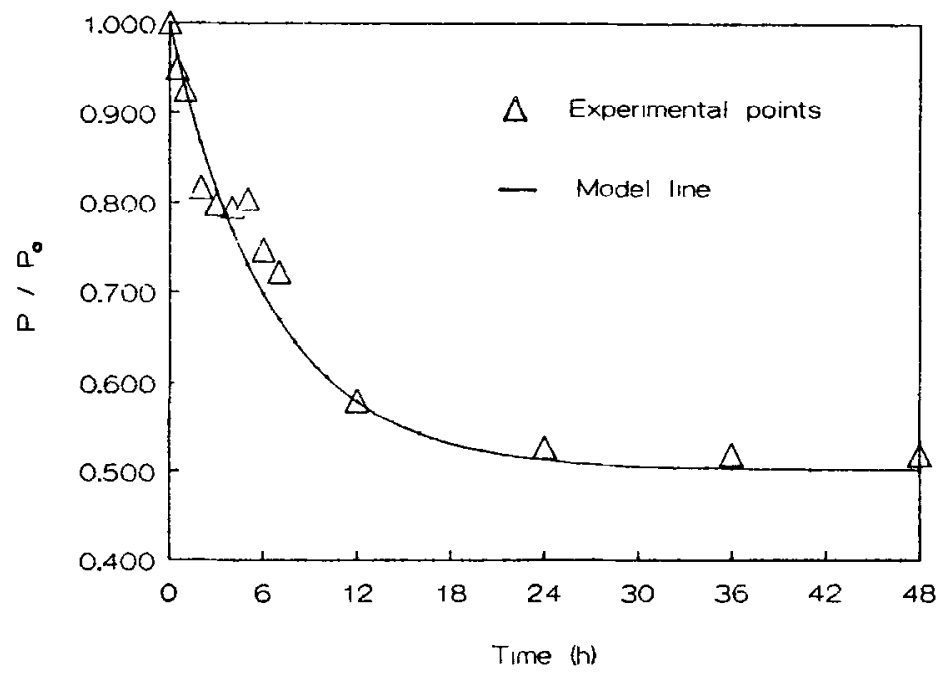

Figure 5: Adsorption kinetics of lactase/CM-Sephadex system

As seen in Figure 5, approximately 22\% of adsorption occurred in about 4 hours time. The equilibrium has been attained after 24 hours with an adsorption yield of approximately 40-50\%.

The dynamic model proposed for the protein/ion-exchanger systems described above closely fit the experimental data. Adsorption kinetics of this system is considered to be slow, this can be because of the size of the enzyme molecule (MW 200.000 Da, $D_{\mathrm{m}}=4.2 * 10^{-11} \mathrm{~m}^{2} / \mathrm{sec}$ ).

This model assumes that kinetics can be described in terms of a lumped mass transfer coefficient involving internal and 
external resistances. The global mass transfer coefficient ka can be estimated from the initial rate of adsorption, assuming that at $t \approx 0, p>>p^{*}$ in. Equation $(6)$, ie:

at $t \approx 0$ $-d p / d t=k$ a $p$

Integration yields: $\quad \ln \left(p / p_{0}\right)=-k$ a $t$

Therefore a plot of $\ln \left(\mathrm{p} / \mathrm{p}_{0}\right)$ versus $t$ for experimental points at early stages of adsorption should yield a straight line with slope $=-\mathrm{ka}$.

Estimated apparent mass transfer coefficient ( $k$ ) values are shown in Table 1 as a function of particle size.

Table 1: Mass transfer coefficients

\begin{tabular}{|c|c|c|}
\hline $\begin{array}{c}\text { Hydrated bead } \\
\text { diameter of } \mathrm{CM}- \\
\text { Sephadex }(\mathrm{m})\end{array}$ & $\begin{array}{c}\text { Experimental } \mathrm{k} \\
\left(\mathrm{ms}^{-1}\right)\end{array}$ & $\begin{array}{c}\text { Theoretical } \mathrm{k} \\
\left(\mathrm{ms}^{-1}\right)\end{array}$ \\
\hline $2.0 * 10^{-4}$ & $0.433 * 10^{-7}$ & $3.0 * 10^{-7}$ \\
\hline $6.0 * 10^{-4}$ & $1.3 * 10^{-7}$ & $1.0 * 10^{-7}$ \\
\hline
\end{tabular}

same order of magnitude as that predicted (the differences can be accounted for by the assumption that $\mathrm{Sh}=2$ which corresponds to very low values of $R e$, for a sphere in an unstirred liquid).

Experiments show that this single parameter model gives a reasonable description of the adsorption kinetics for lactase/CMSephadex system.

It can be concluded that data obtained from the experiments can be used for the designing of a lactase enzyme immobilization + separation and purification process using ion-exhange chromatography.

a

$\mathrm{D}_{\mathrm{m}}$

$e_{1}, e_{2}$

$\mathrm{k}$

ka

$\mathrm{f}$

NOMENCLATURE

specific mass transfer area

molecular diffusion coefficient $\left(\mathrm{m}^{2} / \mathrm{sec}\right)$

charge of the protein and the gel

apparent mass transfer coefficient $\left(\mathrm{s}^{-1}\right)$

global mass transfer coefficient

partition coefficient

$\mathrm{K}_{\mathrm{p}}$

$\mathrm{p}$

dissociation constant for adsorbent-adsorbate complex, (mg/mL solvent)

equilibrium concentration of free enzyme, (mg free enzyme/mL solution)

q equilibrium concentration of adsorbed enzyme, (mg ads./mL gel)

$\mathrm{q}_{\mathrm{m}} \quad$ maximum adsorption capacity, (mg ads./ml gel)

Re particle Reynolds number

Sh Sherwood number

$\mathrm{V}_{\mathrm{g}} / \mathrm{V}$ gel volume (mL)/bulk solvent volume (mL)

$\mathrm{Z}$ dimensionless extent of adsorption

$\alpha \quad \mathrm{K}_{\mathrm{p}} / \mathrm{p}_{\circ}$, model parameter

$\alpha^{\prime} \quad(\alpha / \beta)+1$, model parameter

$\beta \quad \mathrm{V}_{\mathrm{g}} \mathrm{q}_{\mathrm{m}} / \mathrm{V} \mathrm{p}_{0}$, model parameter

REFERENCES

Harsa, S., Pyle, D.L. \& Zaror, C.A. (1990). In: Separations for Biotechnology 2, (Ed. D.L. Pyle). Elsevier Applied Science pp 658 .

Harsa, S., Zaror, C.A. \& Pyle, D.L. (1993). Enzyme and Microbial Techn. 15: 906-915. 